\title{
PENERAPAN INTERNET OF THINGS (IOT) UNTUK KONTROL LAMPU MENGGUNAKAN ARDUINO BERBASIS WEB
}

\author{
Budi Artono, Rakhmad Gusta Putra \\ Teknik Komputer Kontrol, Politeknik Negeri Madiun \\ Email: budiartono@pnm.ac.id, gusta@pnm.ac.id
}

\begin{abstract}
The existence of the internet in the midst of humans, has given a lot of changes, both in life to interact, communicate, be social and cultured. The internet can change the world. We already know and enjoy the convenience - convenience that starts from the internet. The presence of the internet as a liaison between human communication has changed the world. The internet is not only to connect communication between people, but has connected many devices even anything that can be connected, Internet of Things or abbreviated IoT. The Internet of Things is an implementation of network communication of interrelated objects, connected to one another and communicate with each other. Smartphones that have been scattered at this time can be said to be a device capable of developing IoT. Smartphones have the ability to connect to the internet and are equipped with sensor features. To develop IoT, the sensor must be able to communicate with other devices by pairing an application that makes it capable of doing so. In the following study a system design was developed using the Arduino microcontroller and with data from the LDR sensor that was communicated wirelessly by connecting to the Internet via WiFi by sending data to an open source site (cayenne.mydevices.com). Cayenne is one of the IoT (Internet of Things) platforms that function as a server that stores project control and monitoring a device and supports connection with various types of microcontrollers, this platform is very user-friendly and has various types of connections in connecting between microcontrollers and platforms Internet. The result of the design is the automatic light control system through the Cayenne IoT platform on the web and mobile phone from the application. The design of this project is expected to be developed for IoT (Internet of Things)
\end{abstract}

Kata kunci-Internet of Things, Control system, LDR, Arduino.

\section{Pendahuluan}

Lampu merupakan sumber cahaya yang sangat penting sebagai pengganti matahari. Penggunaan lampu dimasyarakat sekarang ini dinilai kurang efektif dan masih sering mengabaikan penggunaannya, sering kali lampu masih tetap menyala walaupun tidak dipakai. Hal semacam ini merupakan suatu pemborosan. Disisi lain proses mematikan dan menghidupkan lampu secara manual masih dirasa banyak membuang banyak waktu. Oleh karena itu perlu dibuat suatu sistem kontrol lampu serta system yang mampu untuk memoitor agar penggunaannya menjadi menjadi lebih efektif efesien.

Internet sebagai bagian dari perkembangan teknologi yang sangat berkembang pesat dikehidupan masyarakat saat ini telah mampu untuk digunakan sebagai media komunikasi dan kontrol terhadap perangkat dari jarak jauh selama masih terkoneksi untuk saling terhubung.
Internet of Things (IoT) merupakan sebuah pengembangan komunikasi jaringan dari benda yang saling terkait, terhubung satu dengan yang lain lewat komunikasi internet serta untuk saling bertukar data yang kemudian dapat mengubahnya menjadi informasi.

Cayenne adalah platform IoT (Internet of Things) yang sekaligus berfungsi sebagai server yang mampu menyimpan project yang sedang dibuat. Cayenne mendukung dan sangat support terhadap berbagai jenis mikrokontroler. Pada cayenne selain berbagai kelebihannya tersebut, masih ada fitur yang membuat Cayenne lebih user-friendly yaitu adanya aplikasi berbasis smartphone dengan OS Android, IOS, maupun Windows Phone sehingga memudahkan dalam membuat berbagai jenis perangkat elektronik dengan kendali jarak jauh melalui internet.

Penelitian terdahulu telah dibuat tentang " $L E D$ control system with cayenne framework for the Internet of Things 
(IoT)" yang telah berhasil menghasilkan sebuah sistem kontrol LED dengan memanfaatkan cayenne melalui internet sebagai kontrol dengan media koneksi jaringan wifi [1]. Penelitian yang lain dengan judul "Pembuatan Prototipe Lampu Otomatis Untuk Penghematan Energi Berbasis Arduino di Departemen Fisika Fmipa IPB" telah menghasilkan prototipe lampu otomatis berbasis Arduino yang berfungsi untuk penghematan energi [2]. Selanjutnya penelitian dengan judul "Prototype Rancangan Alat Pengendali Lampu Gedung Berbasis Android Dengan Mikrokontroller At89c2051" telah dibuat sebuah kendali lampu gedung yang bisa diakses melalui smartphone android dengan memanfaatkan koneksi internet serta aplikasi yang sudah terinstall pada smartphone android untuk menyalakan dan mematikan lampu. Sistem ini menggunakan komunikasi antara smartphone dengan mikrokontroller AT 89C2051 [3]. Berikutnya penelitian dengan judul "Development of a Low-Cost Internet-of-Things (IoT) System for Monitoring Soil Water Potential Using Watermark 200SS Sensors" telah dapat difungsikan untuk pemantauan kelembaban tanah dengan menggunakan mikrokontroler berbasis Arduino dan data dari sensor yang dikomunikasikan secara nirkabel menggunakan radio ke penerima, dengan menghubungkannya ke Internet via $\mathrm{WiFi}$ dan mengirimkan datanya ke situs open source (ThingSpeak.com) sehingga dapat divisualisasikan [4].

\section{Metodologi}

\section{A. Internet of Things (IoT)}

Berinteraksi dan berkomunikasi antara manusia dengan manusia merupakan sesuatu hal yang sudah sangat umum dan biasa dilakukan, begitu pula interaksi antara manusia dengan mesin, bagaimana jika interaksi tersebut adalah mesin dengan mesin tentu semua dimulai dan berawal dari ditemukannya teknologi seperti computer, jaringan internet, mikroprosessor, sensor dan juga gadget atau devices yang lain. Dituliskan dalam sebuah karya ilmiah dalam McKinsey Global Institute, bahwa internet of things adalah sebuah teknologi yang memungkinkan kita untuk menghubungkan mesin, peralatan, dan benda fisik lainnya dengan sensor jaringan dan aktuator untuk memperoleh data dan mengelola kinerjanya sendiri, sehingga dimungkinkan adanya mesin untuk saling berkolaborasi dan bahkan bertindak berdasarkan informasi baru yang diperoleh secara independen. Sebuah publikasi mengenai Internet of things menjelaskan bahwa internet of things adalah suatu keadaan ketika benda memiliki identitas, bisa beroperasi secara intelijen, dan bisa berkomunikasi dengan sosial, lingkungan, dan penggunanya. Tujuannya adalah untuk membuat manusia berinteraksi dengan benda lebih mudah, bahkan dengan tujuan supaya benda juga bisa saling berkomunikasi dengan benda yang lainnya.

Menurut McKinsey Global Institute, dalam sebuah artikelnya yang ditullis oleh Michael Hendrix, dijelaskan bahwa internet of things akan menjadi salah satu teknologi yang akan gencar di masa depan. Internet of things diprediksi akan membawa pengaruh perkembangan dari sisi ekonomi dengan memberikan peluang mencapai besar 2.7 sampai 6.2 triliun Dolar Amerika Serikat. Pengaruh ekonomi ini dilihat dari industri internet of things yang akan menempati posisi ketiga terbesar setelah mobile internet dan automation of knowledge work. Hal ini membuktikan bahwa teknologi internet of things akan benar-benar berkembang dan menjadikan sebuah tren tesendiri di dunia nantinya.

Beberapa tahun ini kita sudah melihat bagaimana sensor-sensor berkembang dan memengaruhi perkembangan dan kemajuan teknologi di dunia. Tentu akan banyak perusahaan yang menggunakan internet of things, dan berusaha untuk mengembangkannya. Internet of things saat ini masih bisa dikatakan sesuatu yang sangat baru dan masih bisa dikembangkan.

Contoh dalam perkembangan internet of things yang sudah dan masih dimungkinkan untuk dapat dikembangkan lagi adalah Internet of things yang difungsikan sebagai pemantauan jarak jauh, sistem ini merupakan salah satu bentuk sistem aplikasi yang paling sering ditemukan. Salah satu caranya adalah dengan menambahkan sensor pada suatu objek benda yang ingin dipantau atau dimonitor untuk mengetahui keberadaanya atau bahkan kondisi juga tata letaknya, Sensor tersebut dikoneksikan dengan internet dengan menambahkan sebuah pemetaan atau mapping sehingga bisa diketahui letak posisinya. Dengan demikian, akan diperoleh data apa saja yang dibutuhkan dari sensor tadi, dan dapat difungsikan untuk memantaunya dari jarak jauh dengan jaringan internet, bahkan dapat langsung dipantau dengan menggunakan handphone yang sudah mendukung untuk koneksi internet.

Contoh lain dalam dunia kesehatan adalah dengan menambahkan sensor yang dapat mendeteksi temperatur, suhu, kelembaban, atau bahkan tekanan udara yang dipasangkan atau ditambahkan pada alat yag dipakai langsung oleh pasien sehingga dapat memudahkan seorang dokter dalam memantau dan memonitor kondisi pasien. Dengan adanya internet of things seorang dokter 
dapat dimudahkan dalam memantau, memeriksa dan menangani pasiennya setiap hari. Inovasi-inovasi ini sangat membantu dan apabila mampu diterapkan dapat menghasilkan penghematan biaya yang cukup besar.

Mudah mengatakan bahwa smartphone yang saat ini ada adalah merupakan perangkat IoT. Smartphone saat ini sudah memiliki kemampuan untuk terkoneksi dengan internet, dan sudah dilengkapi dengan beberapa sensor seperti layar sentuh, sensor cahaya, akselerometer, gyroskop, dan kompas. Akan tetapi satu hal yang terpenting dalam IoT, bahwa sensor-sensor ini harus dapat mendeteksi dan berkomunikasi dengan perangkat lain, dan ini yang tidak ditemukan pada smartphone terkecuali kita memasang aplikasi yang membuatnya melakukan hal tersebut.

Dengan perkembangan teknologi khususnya mikrokontroler dan jaringan komputer serta internet of thing tersebut dapat memudahkan segala bentuk aktifitas kehidupan manusia. Semua sebenarnya bermula pada saat awal tahun 90-an orang mulai mengenal teknologi Internet of Things. Mark Weiser seorang staf Xerox Palo Alto Research Center pada tahun 1991 menerbitkan paper tentang ubiquitous computing dengan judul "The Computer of the 21 st Century" yang menjelaskan tentang visi kontemporer yang berkaitan langsung dengan perkembangan teknologi internet of thing saat ini [5].

Internet of Things muncul dan diperkenalkan sebenarnya oleh Kevin Ashton, seorang entrepreneur yang fokus terhadap teknologi asal UK. Istilah Internet of Things pertama kali dipakai sebagai judul presentasi dalam seminarnya di depan perusahaan penyedia produk harian dari Amerika, Procter \& Gamble (P\&G). Kevin menjelaskan bahwa IoT sebagai sistem dimana bendabenda fisik dapat saling terhubung ke internet melalui sensor yang ada di mana-mana [6].

Internet of things pada dasarnya adalah dapat dimulai dengan cara membuat suatu koneksi atau sebuah komunikasi antara mesin dengan mesin, sehingga mesin mesin tersebut dapat berinteraksi dan dapat bekerja secara independen sesuai dengan data yang diperoleh yang kemudian dapat mengolahnya secara mandiri. Sistem IoT dapat tumbuh menjadi lebih kompleks dengan sejumlah besar perangkat yang dapat saling berhubungan untuk menghasilkan layanan yang mendukung untuk proses yang lebih kompleks. Seperti yang digambarkan pada Gambar 1.

"Internet of Things dapat digambarkan sebagai sebuah jaringan yang mampu untuk melakukan konfigurasi sendiri, serta adaptif, sehingga membentuk sebuah jaringan kompleks yang saling berhubungan dengan berbagai perangkat ke Internet melalui penggunaan protokol komunikasi standar". [7]

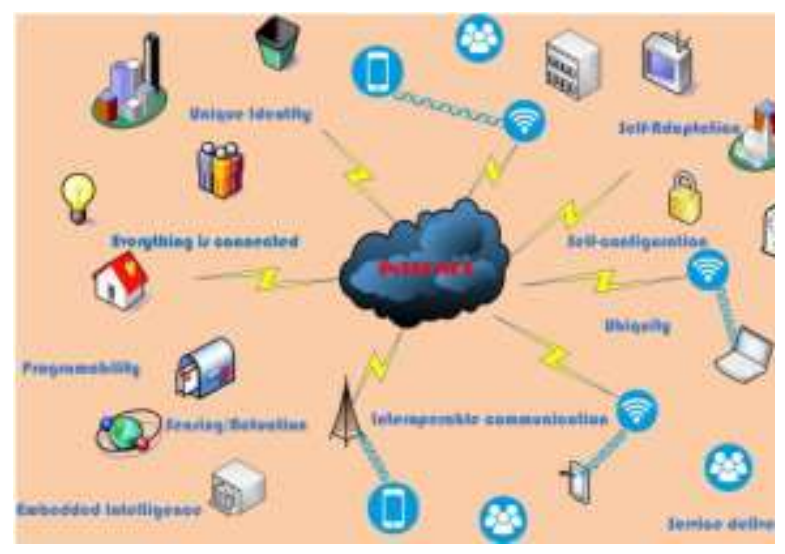

Gambar 1. Fitur dan ruang lingkup sistem IoT [7]

\section{B. Arduino}

Arduino adalah modul elektronik open source berbasis mikrokontroller Atmel AVR Atmega328. Arduino dirancang untuk memudahkan dalam perancangan prototipe hardware elektronik. Modul ini memiliki 14 pin digital input/output, 6 analog input, dan 5 volt power input yang dapat disediakan melalui power supply eksternal maupun konektor USB yang telah disediakan. Selain itu terdapat sebuah tombol reset yang dapat digunakan untuk menjalankan program yang telah di-upload kedalam chip dari awal. Masing-masing pin digital dapat berfungsi sebagai input atau output, tergantung kebutuhan pengguna yang dapat dipilih melalui coding program. Terdapat beberapa versi Arduino, Arduino Rev. 3 adalah versi yang dirilis pada tahun 2012. Arduino dapat diprogram menggunakan software Arduino Sketch dengan menggunakan bahasa pemrograman $\mathrm{C}$.

Di dalam Arduino tidak diperlukan lagi perangkat chip progammer karena didalamnya sudah ada bootloader yang difungsikan untuk menangani upload program dari komputer. Selain itu Arduino juga sudah memiliki sarana komunikasi USB, sehingga pengguna laptop dapat menggunakan port USB yang memiliki modul siap pakai (Shield) yang bisa ditancapkan pada Board Arduino. Input dan Output berupa data digital dan data analog yang dapat langsung menghubungkan Arduino dengan komponen pada pin-pin yang sudah disediakan pada arduino.

\section{Modul Wifi ESP8266}

ESP8266 merupakan modul wifi yang berfungsi 
sebagai perangkat tambahan mikrokontroler seperti Arduino agar dapat terhubung langsung dengan wifi dan membuat koneksi TCP/IP. Modul ini memiliki tiga mode wifi yaitu Station, Access Point dan Both. Modul ini juga dilengkapi dengan prosesor, memori dan GPIO dimana jumlah pin bergantung dengan jenis ESP8266 yang kita gunakan. Sehingga modul ini bisa berdiri sendiri tanpa menggunakan mikrokontroler apapun karena sudah memiliki perlengkapan layaknya mikrokontroler.

Firmware default yang digunakan oleh perangkat ini menggunakan AT Command, selain itu ada beberapa Firmware SDK yang digunakan oleh perangkat ini berbasis open source yang diantaranya adalah sebagai berikut:
a) Node $\mathrm{MCU}$ dengan menggunakan basic programming lua.
b) MicroPython dengan menggunakan basic programming python.

c) $A T$ Command dengan menggunakan perintah perintah AT command.

Untuk pemrogramannya sendiri kita bisa menggunakan ESPlorer untuk Firmware berbasis Node MCU dan menggunakan putty sebagai terminal control untuk $A T$ Command. Untuk pemrogramannya sendiri kita bisa menggunakan ESPlorer untuk Firmware berbasis Node $M C U$ dan menggunakan putty sebagai terminal control untuk AT Command.

\section{Relay}

Relay adalah komponen elektronika berupa saklar elektronik yang digerakkan oleh arus listrik. Secara prinsip, relay merupakan tuas saklar dengan lilitan kawat pada batang besi (solenoid) di dekatnya. Ketika solenoid dialiri arus listrik, tuas akan tertarik karena adanya gaya magnet yang terjadi pada solenoid sehingga kontak saklar akan menutup. Pada saat arus dihentikan, gaya magnet akan hilang, tuas akan kembali ke posisi semula dan kontak saklar kembali terbuka.

\section{E. Cayenne}

Sebuah platform pengembang IoT milik myDevices yang menyediakan akses untuk fitur Arduino dengan berbagai macam shield termasuk di dalamnya terdapat Wi-fi, BLE, IR, NFC, dan lain sebagainya. Platform ini dibangun dengan tujuan mempermudah pembangunan IoT, menyediakan tools yang dapat digunakan untuk memvisualisasikan data yang diperoleh dari sensor, maupun mengendalikan aktuator yang terhubung dengan layanan, melalui web dashboard ataupun aplikasi mobile. Cayanne menawarkan kemudahan dalam mengatur, melakukan konfigurasi, dan integrasi dengan hanya menggunakan metode drag-and-drop untuk papan pengelolanya.

\section{F. Perancangan sistem}

Perancanagan sistem ini dilakukan dengan perencanaan sistem, implementasi sistem dan ujicoba sistem. Untuk mempermudah dalam merancang dan membuat sistem penerapan Internet Of Things (IoT) untuk kontrol lampu menggunakan arduino berbasis web ini, Dirancang Diagram Blok Sistem sebagai :

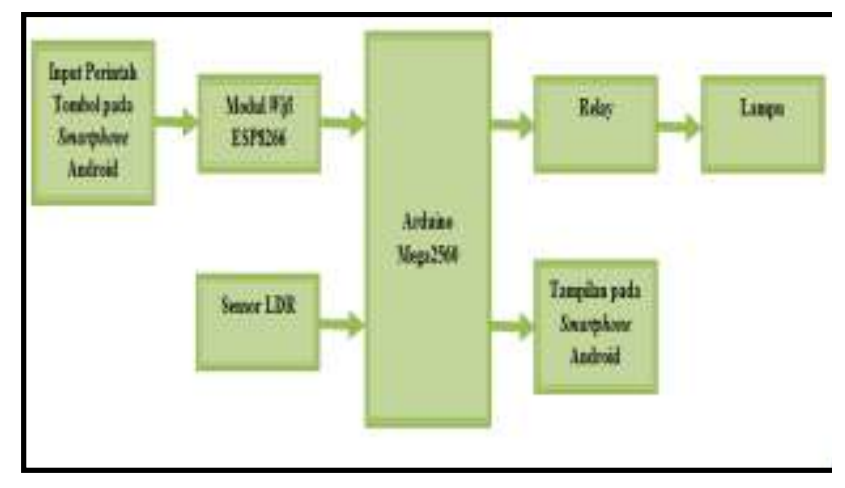

Gambar 2. Rangkaian kontrol lampu IoT

Dari blok diagram sistem diatas dapat dijelaskan sebagai berikut:

1. Input Perintah Tombol : Berfungsi untuk mengirim perintah berupa sentuhan tombol untuk menyalakan atau mematikan lampu secara manual (sebagai pengganti saklar) pada handphone android dengan aplikasi cayenne.

2. Wifi: Media komunikasi antara cayenne / android dan arduino.

3. Sensor LDR : Untuk memberikan inputan perintah berupa gerakan untuk menyalakan atau mematikan lampu secara otomatis.

4. Arduino : Sebagai mikro untuk memproses dan mengolah data.

5. Relay: Untuk mengaktifkan dan mematikan lampu.

6. Lampu: Lampu untuk ON/OFF

Prinsip kerja dari penerapan Internet Of Things (IoT) untuk kontrol lampu menggunakan Arduino berbasis web ini adalah sebagai berikut:

1. Alat ini dapat bekerja secara manual maupun secara otomatis. Secara manual dapat menggunakan saklar yang ada pada project 
aplikasi cayenne dan secara otomatis dengan menggunakan sensor LDR yang terdeteksi oleh project cayenne. Apabila menggunakan smartphone android, maka smartphone android harus terhubung dengan modul wifi ESP8266.

2. Sebagai inputan pada sistem ini berasal dari project aplikasi cayenne berupa button dan juga dari sensor LDR yang digunakan. Melalui button pada aplikasi cayenne dan sensor LDR yang sudah terhubung dengan modul wifi ESP8266 perintah akan diterima dan diproses oleh Arduino.

3. Kemudian perintah pada Arduino akan diproses dan selanjutnya akan dikirim ke relay. Relay akan merespon data yang dikirim oleh Arduino yang akan digunakan untuk menghidupkan dan mematikan lampu sesuai dengan perintah.

4. Sensor cahaya LDR akan menentukan kondisi relay aktif atau tidak aktif. Kemudian data akan dikirim ke project aplikasi cayenne melalui modul wifi ESP8266 untuk ditampilkan.

5. Pada perangkat smartphone android akan mendeteksi kondisi relay, apabila "ON" maka kondisi lampu menyala sedangkan apabila "OFF" maka kondisi lampu mati.

\section{Hasil dan Analisa}

Pada bagian ini akan dijelaskan proses pembuatan peralatan dari penerapan Internet Of Things (IoT) untuk kontrol lampu menggunakan Arduino berbasis web yang terdiri dari hardware lampu yang sudah dirangkai dengan wifi shield, arduino dan relay.

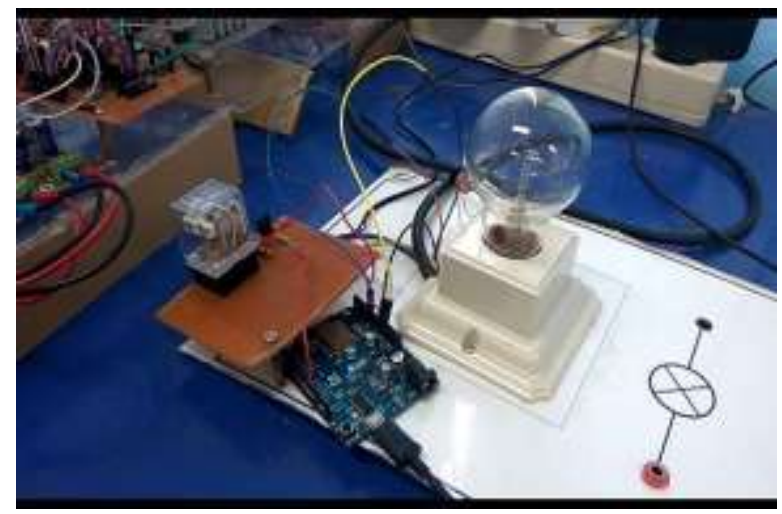

Gambar 3. Rangkaian kontrol lampu IoT

Setelah rangkaian hardware sudah dirancang proses berikutnya adalah membuat project di platform cayenne.mydevices.com

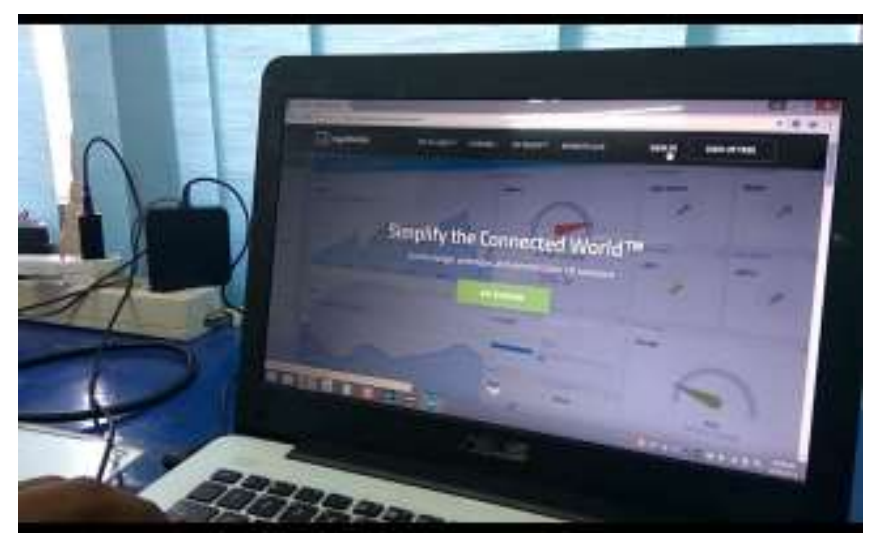

Gambar 4. Tampilan dashboard pada web Cayenne.mydevice.com

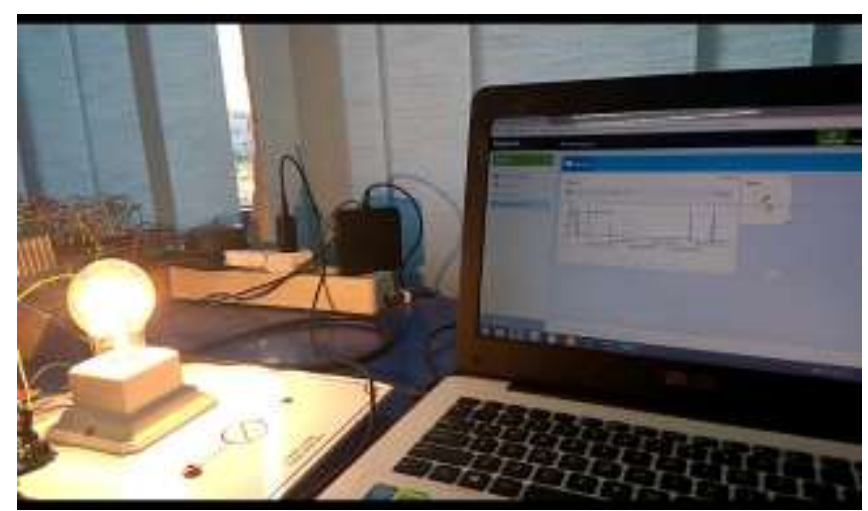

Gambar 5. Kondisi lampu menyala dan hasil monitoring grafik nilai data dari sensor LDR dengan cayenne

Pengujian pertama pada penerapan Internet Of Things (IoT) untuk kontrol lampu menggunakan Arduino berbasis web adalah dengan memberi inputan secara manual dengan menekan tombol button pada aplikasi cayenne sehingga pada dashboard akan ditampilkan virtualisasi lampu dengan kondisi nyala atau mati. Proses berikutnya adalah dengan melakukan pengujian secara otomatis dimana sensor LDR akan medeteksi kondisi lampu pada saat kondisi nyala atau kondisi mati yang kemudian data akan ditampilkan di tampilan visual pada dashboard cayenne.

Pengujian yang ke dua penerapan Internet Of Things (IoT) untuk kontrol lampu menggunakan Arduino berbasis web ini adalah dengan menggunakan handphone O.S android sebagai kontrol dan juga sebagai monitor untuk mengetahui kondisi lampu dengan menggunakan aplikasi cayenne visualisasi tampilan dashboard pada aplikasi cayenne akan menunjukkan hasil proses kontrol lampu berhasil. Proses berikutnya adalah dengan melakukan pengujian secara otomatis dimana sensor LDR akan medeteksi kondisi lampu pada saat kondisi nyala 
atau kondisi mati yang kemudian data akan ditampilkan di tampilan visual pada dashboard cayenne pada handphone android.

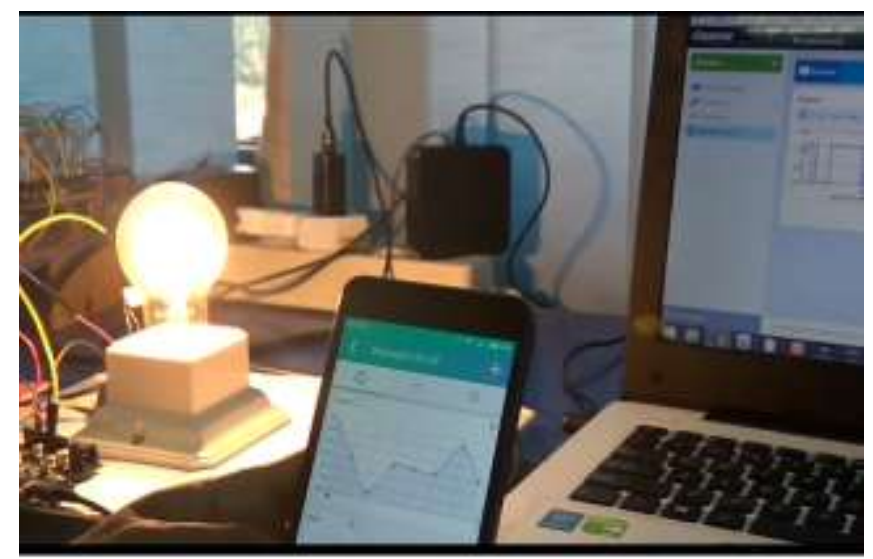

Gambar 6. Kondisi lampu menyala dan hasil monitoring grafik nilai data dari sensor LDR dengan cayenne di web dan aplikasi pada handphone

Pada pengujian ke tiga penerapan Internet Of Things (IoT) untuk kontrol lampu menggunakan Arduino berbasis web adalah dengan mematikan lampu secara manual untuk mengetahui pengaruhnya terhadap data dari sensor LDR. Tampilan dashboard pada aplikasi cayenne akan menunjukkan hasil proses kontrol lampu dan data yang ditampilkan dari aplikasi cayenne menunjukkan sensor mendekati ke data nol kemudian data akan ditampilkan di tampilan visual pada dashboard cayenne pada handphone android.

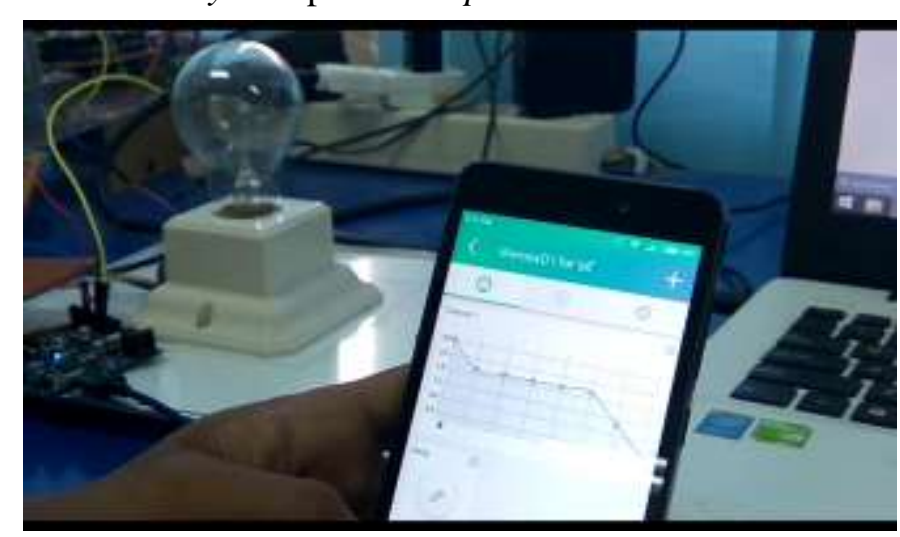

Gambar 7. Kondisi lampu mati dan hasil monitoring grafik nilai data dari sensor LDR dengan cayenne di web dan aplikasi pada handphone

Pengujian yang ke empat pada penerapan Internet $O f$ Things (IoT) untuk kontrol lampu menggunakan Arduino berbasis web adalah dengan menyalakan lampu secara manual untuk mengetahui pengaruh terhadap data dari sensor LDR. Tampilan dashboard pada aplikasi cayenne menunjukkan hasil proses kontrol lampu dan data yang ditampilkan dari aplikasi cayenne menunjukkan sensor LDR bekerja dengan intesitas cahaya ditampilkan pada visualisasi dashboard aplikasi cayenne pada handphone android.

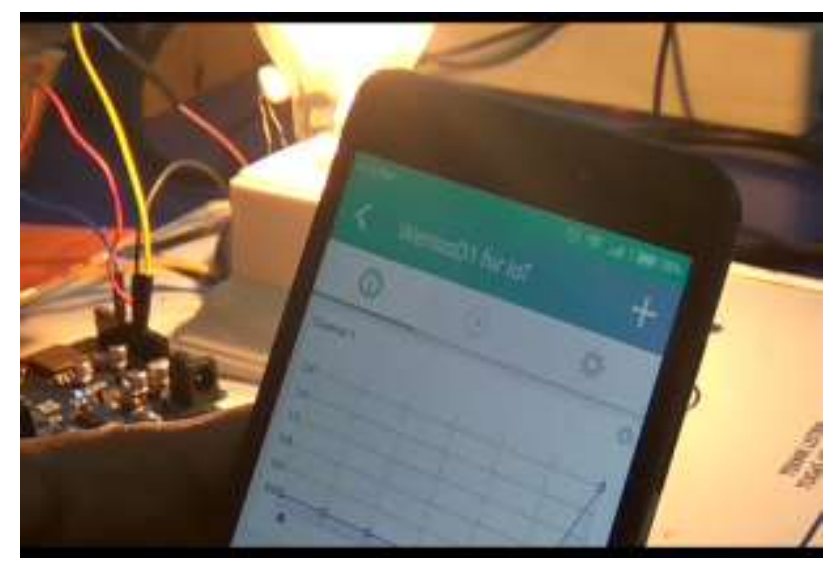

Gambar 8. Kondisi lampu saat mulai menyala dan hasil monitoring grafik nilai data dari sensor LDR dengan cayenne di aplikasi pada handphone

\section{Kesimpulan}

Berdasarkan uraian diatas maka diperoleh kesimpulan terhadap keseluruhan proses adalah sebagai berikut :

- Sistem dapat memonitor dan dapat difungsikan untuk pengendali lampu dengan project web yang dibuat di aplikasi cayenne. Dari web dan aplikasi cayenne di smartphone dapat diketahui apakah kondisi lampu dalam keadaan hidup atau mati.

- Sensor cahaya LDR bekerja dengan baik sebagai input data dari sistem pengendali lampu. Data didapat dapat dikirim ke aplikasi cayenne melalui wifi. Apabila nilai resistansi LDR tinggi maka lampu dalam kondisi hidup, sebalikanya apabila nilai resistansi LDR rendah maka lampu dalam kondisi mati.

- Sistem pengendali lampu dapat dikontrol secara otomatis dengan aplikasi cayenne dengan memanfaatkan sensor LDR.

\section{Daftar pustaka}

Budi artono, LED control system with cayenne framework for the Internet of Things (IoT), JEECAE Vol.2, No.1, Mei 2017

Nida Nabilah, dkk., Pembuatan Prototipe Lampu Otomatis Untuk Penghematan Energi Berbasis Arduino di Departemen Fisika Fmipa IPB. Prosiding Seminar Nasional Fisika (E-Journal) SNF2016. VOLUME V, OKTOBER 2016 p-ISSN: 2339-0654 e-ISSN: 2476-9398 DOI: doi.org/10.21009/0305020115 http://snf-unj.ac.id/kumpulanprosiding/snf2016/.

[3] Suleman \& Anwar Taufik. 2016. Prototype Rancangan Alat Pengendali Lampu Gedung Berbasis Android Dengan Mikrokontroller At89c2051. Indonesian Journal On Networking And Security Vol. 5 No. 4 Oktober 2016. 
[4] José O. Payero1, dkk., Development of a Low-Cost Internet-of-Things (IoT) System for Monitoring Soil Water Potential Using Watermark 200SS Sensors". Advances in Internet of Things, 2017, 7, 71-86 ISSN Online: 2161-6825 ISSN Print: 2161-6817 http://www.scirp.org/journal/ait

[5] Weiser, M.: The Computer for the 21st Century. Scientific American 265(9):66-75 (1991)

[6] IEEE, Issue 1 MAY 2015, "Towards Definition Internet of Things (IoT)", iot.ieee.org.

[7] Mattern, F., Floerkemeier, C.: From the Internet of Computers to the Internet of Things

[8] Iswanto. 2011. Belajar Microcontroller AT89s51. Yogyakarta: Andi.

[9] Bruhlman, Thomas. 2015. Arduino Praxiseinstieg. Jakarta :MITP.

[10] CodePolitan_Magazine_\#19-Internet_of_Things, Maret 2016

[11] Yuhefizar. 2008. 10 Jam Menguasai Internet Teknologi dan Aplikasi. Jakarta: PT.Elex Media Komputindo.

[12] Malvino, Albert Paul. 1999. Prinsip-prinsip Elektronika Jilid II. Jakarta: Erlangga.

[13] Tanenbaum, AS, Computer Networks, Prentise Hall, 1996

[14] Stallings, W. Data and Computer Communications, Macmillan Publishing Company, 1985

[15] Black, U.D, Data Communications and Distributed Networks, Prentise Hall.

[16] https://cayenne.mydevices.com/ 
Penerapan Internet Of Things (Iot) Untuk Kontrol Lampu 